\title{
The systems of managing wildlife and forest in central Europe
}

\author{
by B. Bobek ${ }^{1}$, K. Perzanowski ${ }^{1}$, S. Kossak ${ }^{2}$ and D. Merta ${ }^{1}$
}

Central European countries share many similarities in the composition of forest habitats and wildlife species. However, the former political division of Europe produced substantial differences in wildlife management systems and land ownership. Forests are generally regarded as a source of lumber with the requirements of wildlife neglected most of the time. There is an urgent need to introduce measures enhancing forest habitats for wildlife. Most important seems to be maintaining and possibly increasing biodiversity by altering present logging systems. In future, production of timber should become only one of several functions of forests including conservation of wildlife, recreation, and other values.

Not long ago, there were still two different political systems in Central Europe. That shaped the present principles of forest and game management within this region. In the Czech Republic, Hungary, Poland, and Slovakia, most forests and all wildlife species are national property. Thus, forest management in these countries is mostly performed by State Forest Services. However, game management in forests is generally done by hunters associated with hunting clubs and, to a lesser degree, by State Forest Services. In other Central European countries, forests are mostly privately owned, and wildlife belongs to the landowner, who also is responsible for forest and wildlife management (Myrberget 1990).

Apart from these differences, forest and game management in the region are somewhat similar in all neighbouring countries. Due to geographical vicinity, all these countries share the most important commercial tree species (pine, spruce, fir, larch, oak, beech, and ash) and big game species (red deer, roe deer, wild boar). Game management is based on hunting districts, rarely exceeding $50 \mathrm{~km}^{2}$, but with well-defined minimal size. Hunters are subjected to compulsory training and in general belong to hunters associations. They are obliged to maintain the numbers of ungulates at a level not exceeding theoretical carrying capacity, (i.e., below possible occurrence of damage to a forest stand), provide supplemental food in winter, and to compensate farmers for damage to field crops. Game management is focussed on trophies rather than on obtaining the maximal yield of venison. State Forest Administration merely supervises whether management practices are performed by forest owners and ensures that hunters follow national rules.

In general, the function of State Forest Administration in controlling wildlife habitats may be substantial in countries where vast forested areas were nationalised, but much lower if the majority of the forest is privately owned. It is quite rare, however,

'Department of Wildlife Research, Jagiellonian University, Ingardena 6, 30-060 Kraków, Poland.

${ }^{2}$ Institute of Forest Research, 12-230 Bialowieza, Poland.
Les pays de l'Europe centrale partagent plusieurs similitudes au niveau de la composition des habitats forestiers et des espèces fauniques. Cependant, la précédente division politique de l'Europe a généré des différences substantielles dans les systèmes d'aménagement faunique et de propriétés du territoire. Les forêts sont généralement considérée comme une source de bois de sciage alors que les besoins de la faune sont laissés pour compte la plupart du temps. Il faut de façon pressante introduire des mesures qui amélioreront les habitats forestiers destinés à la faune. Il faut avant tout maintenir et probablement augmenter la biodiversité en modifiant les systèmes actuelles de récolte. À l'avenir, il faudrait que la production de bois sciage devienne seulement l'une des quelques fonctions des forêts comme la conservation de la faune, la récréation et les autres valeurs. for State Forest Administration to directly perform game and forest management within the same area. Even if the percentage of state forests is high, wildlife management is mostly exercised by hunters.

Within the whole region, forest and wildlife management follow clearly defined national principles focussed on the production of timber and minimising damage by wild ungulates. Thus, wildlife is regarded as a by-product of timber management, and enhancing or reducing the quality of wildlife habitat results from forest practices aimed at maximal production of timber.

General rules of forest management require forest owners to follow certain regulations. The most important are: (1) the amount of timber allowed (or designated) for logging and the minimal age of a stand allowed to be cut; (2) reforestation following prescribed composition of tree species; (3) locally allowed logging system (clearcut or selective), maximal area of a clearcut and thinning schedule; (4) reconstruction of forest stands (if necessary); and (5) sanitary and fire protection.

On the other hand, general rules oblige wildlife managers to minimise damage that might be caused by ungulates in reforested areas, plantations or thickets. That requires the following practices: (1) maintaining the densities of wild ungulates at carrying capacity of a given habitat; (2) applying a selective shooting system towards ungulates for sex, age and antler class; (3) providing supplemental food in winter; (4) compensating for damage to field crops; and (5) reducing ungulate numbers in case of excessive damage to forest stands.

Such rules considerably limit the hunters' potential to enhance habitats for wildlife. A much broader scope of possible activities is available for Forest Services supervising or performing forest management, especially where it also exercises game management. Occasionally, the improvement of wildlife habitat occurs due to the local initiative of a landowner who treats wildlife and forest management on an equal basis. There still exists a lack of clearly defined regulations to impose the application of techniques to enhance wildlife habitats. This has caused hunters to focus their efforts on improving the gene pool of big game species by various selective shooting 
systems, leading to the elimination of animals with presumably lower genetic value. Such management is supposed to provide trophies of higher quality. Techniques applied by hunters in order to improve wildlife habitats are of marginal importance and very often only help weaker individuals to survive winter. Thus, the best quality trophies, like red deer antlers, are acquired where wildlife habitats still possess a high degree of biodiversity, and a continental climate.

The following methods, according to foresters and hunters, may improve wildlife habitats:

(1) when forest stands are regenerated or established, an admixture of non-commercial species, characteristic for a given habitat, should be planted. (That suggestion is often neglected by foresters).

(2) Wildlife food plots, usually $2-3$ ha, should be planted with attractive species for ungulates (cereals, root plants, poplars, willows, wild apple trees, etc.). That technique has been applied on a large scale in northeastern Poland with the use of some exotic species, and has helped to decrease damage in plantations and thickets of Scots pine.

(3) Slash treatment could be accomplished by making availble for ungulates the browse and bark from trees cut down in winter. Willows and poplars are most often used in this way, but use of the material obtained after thinning of middle-age classes is also recommended. Such trees left in the forest for 2-3 months were very attractive for moose that otherwise were damaging pine forests in northeastern Poland (Trzcianne Forest District). Afterwards, the material can be removed from the forest and could be sold because such treatment does not diminish the commercial value of the wood (Komenda, Inspector of Game Management, pers. comm.).

(4) Supplemental winter feeding (hay, alfalfa, concentrated forages) and creation of artificial salt licks are techniques that can result in locally high concentrations of ungulates, and result in incremental damage to surrounding forests.

(5) The establishment of "barrier" feeding strips could be designated to prevent wild boars from foraging in fields. Corn or other grain is harrowed usually along forest roads, parallel to the edge of the forest (Vasant et al. 1992) to attract boars. (6) Maintaining small sod openings inside of the forest provides an additional food source for deer and wild boars.

(7) Blueberry patches can be made available for deer in winter by ploughing off snow.

(8) Increasing the number of nesting sites for birds is accomplished by installing bird boxes and leaving dead snags in clearcuts or in windblown areas.

These techniques may improve the quality of wildlife habitats only slightly and for a short time. Their application depends in practice on the good will of the people responsible for wildlife and forest management. On the other hand, research projects focussed on maximal timber yield provided data which formed a basis for obligatory practices in silviculture. Those practices have altered Polish forests, which now serve mainly as timber production areas. Studies on wildlife habitats were started much later together with the increasing value for modern societies (especially non-consumptive value). So far however, results of these studies have not been included in the obligatory principles of forest and game management.

High biodiversity in forest habitats is still well-maintained in forests where timber is harvested selectively, and the structure of the forest is of uneven age. At present, some forests exploited by clearcutting are supposed to become managed under uneven-aged systems. If the logging schedule in these forests favours high basal area and a closed canopy, then food resources for large ungulates will be considerably reduced, resulting in further future reductions in numbers. At the same time, in the forests exploited with clearcuts, it is becoming more common to fence young plantations and thickets, resulting in a sharp reduction of ungulates numbers. Thus, the need to alter the principles of forest management, including factors which influence the quality of forest habitats for wildlife, is becoming very urgent.

According to recent data on the quality of wildlife habitats in the forests of Central Europe the following conclusions are drawn:

(1) Intensive logging and even-aged composition of forest stands have increased food resources for large ungulates. Because the size of a clearcut is usually limited (often $<8 \mathrm{ha}$ ), such areas are intensively used by ungulates leading to heavy damage on seedlings and young trees. Forest plantations and thickets, usually $15-20 \%$ of forested areas, provide almost $80 \%$ of the available browse and herbage (Fig. 1). However, the standing crop of winter-green herbage and browse provided by dwarf shrubs is considerably higher in older stands than in younger forest (Table 1). In stands of older timber, or in forests where the selective cutting system is applied, food resources of large ungulates depend on canopy cover and tree basal area (Table 2).

(2) Commercial forests managed for timber provide a much richer food supply for larger ungulates compared to old growth forest. That was shown in a study from Bialowiesza Forest where old growth stands, maintained as nature reserves since 1921, were compared with adjoining commercial stands (Tables 3 and 4). The importance of old growth forests for large ungulates may increase in mast years, especially in the case of oak stands that may produce up to $1000 \mathrm{~kg} / \mathrm{ha}$ of acorns (BandolaCiolczyk 1974), or beech stands providing up to $80 \mathrm{~g} / \mathrm{ha}$ of beechnuts (Myczkowski 1967).

(3) The optimal habitat for deer should be forest composed of $60-80 \%$ forage and $20-40 \%$ cover (Bobek et al. 1990). Deciduous browse and herbs in summer, and winter-green leaves of blackberry and shoots of blueberry are key components affecting the quality of forest habitats for deer in winter (Bobek et al. $1990 \mathrm{~b})$. Another important factor is the total amount of ecotone, particularly between the forest and meadow, between patches of various conifer species of different ages, and between deciduous and coniferous patches of the same age class (Bobek and Merta 1993).

(4) The quality of habitat for capercaillie primarily depends on canopy cover, height of ground vegetation, percentage of old forest stands, and the amount of forest floor covered by dwarf shrubs providing berries (Storch 1993a, b).

It is difficult to estimate to what extent the results of studies on the quality of forest habitats for wildlife are known to Forest Services. Definitely the information is not included in obligatory forest practices. Thus there is a need to elaborate general principles of forest management, based on ecological studies, to improve the quality of forest habitats for wildlife. These principles should be included in general instructions for forest managers.

Perhaps a possible way to maintain biodiversity in the forests of Central Europe would be to adapt the model presented by Harris (1984). Preservation of a core part of a forest as a structure resembling a natural forest reserve would also protect critical 
YOUNG PLANTATIONS
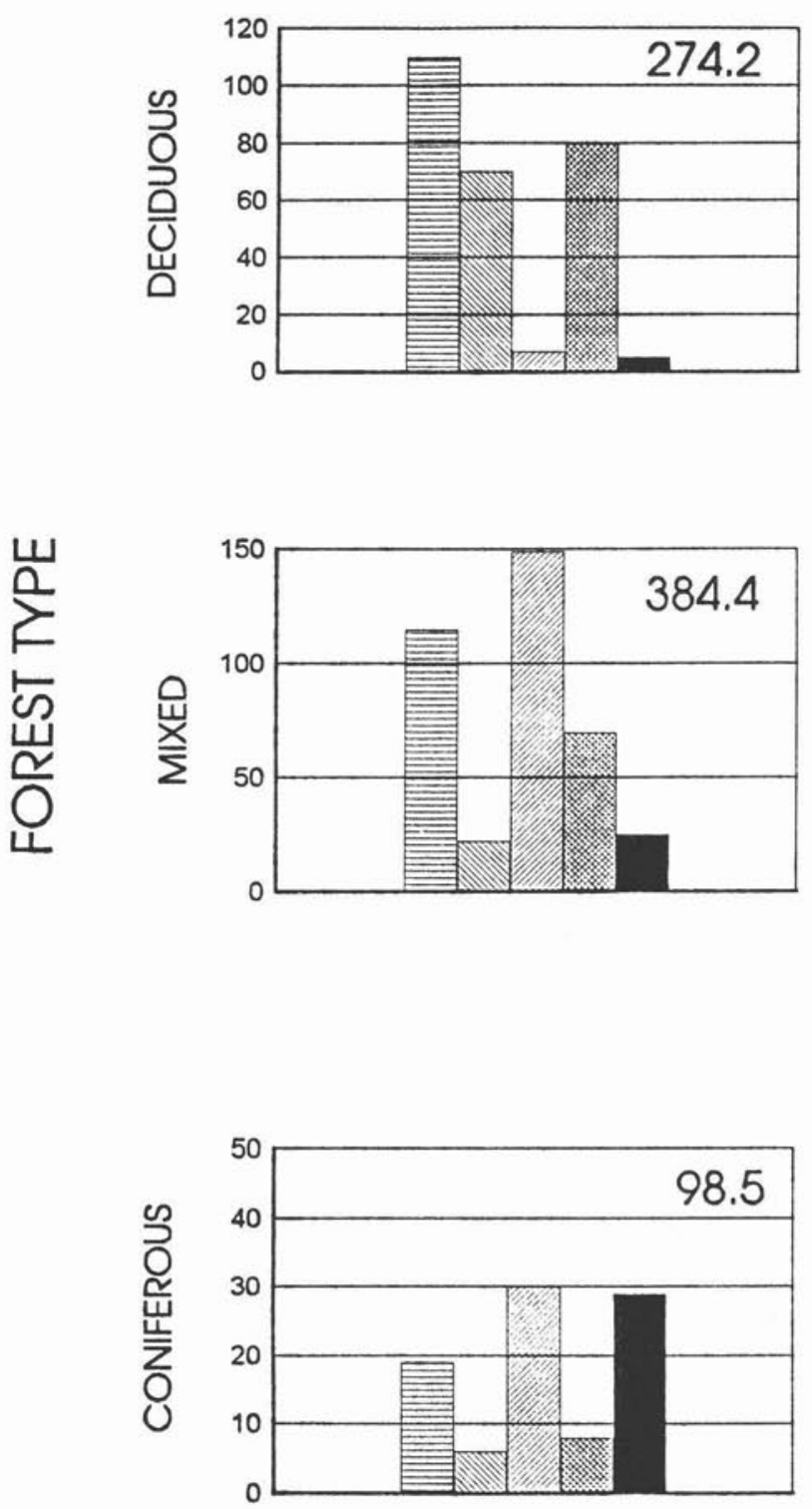

\section{TIMBER STANDS}
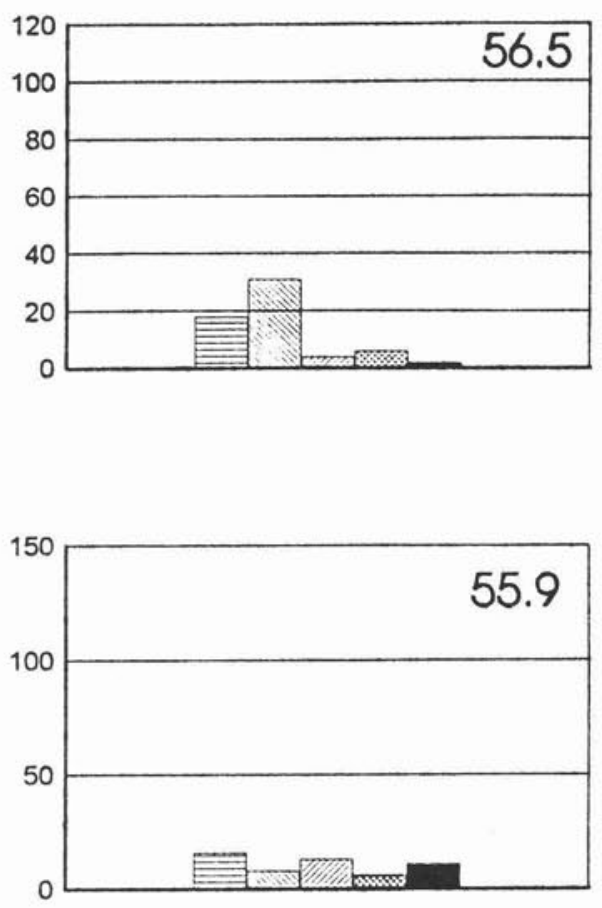

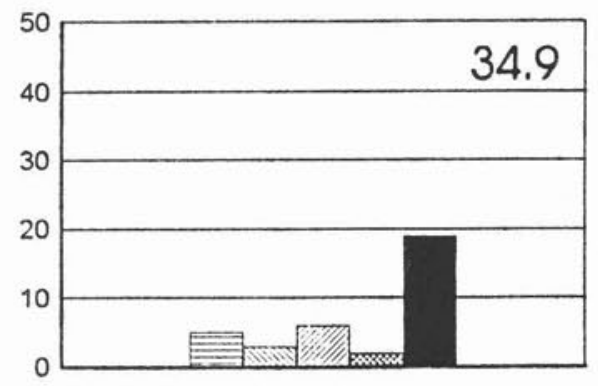

Figure 1. Relative contributions of broad land types to total Polish forest area.

Table 1. Average winter standing crop $\left(\mathrm{g} \mathrm{dw} / \mathrm{m}^{2}\right)$ of annual shoots of dwarf shrubs and green parts of herbs, grasses and sedges in various forest habitats of Polish lowlands. Calculations were based on Barabasz (1990), Bochnia (1990), Bobek et al. (1979), Dzieciolowski (1970), Golecki (1990) and Nabielec (1988). The number of surveyed forest types is given in parentheses.

\begin{tabular}{|c|c|c|c|c|c|c|c|c|}
\hline \multirow[b]{2}{*}{ Forest habitat } & \multicolumn{4}{|c|}{ Plantations and thickets } & \multirow[b]{2}{*}{ Herbs } & \multicolumn{3}{|c|}{ Timber stands } \\
\hline & Herbs & $\begin{array}{c}\text { Grasses } \\
\text { \& sedges }\end{array}$ & $\begin{array}{l}\text { Dwarf- } \\
\text { shrubs }\end{array}$ & Total & & $\begin{array}{c}\text { Grasses } \\
\text { \& sedges }\end{array}$ & $\begin{array}{l}\text { Dwarf- } \\
\text { shrubs }\end{array}$ & Total \\
\hline Deciduous (2) & 4.9 & 3.3 & - & 8.2 & 5.4 & 3.6 & - & 9.0 \\
\hline Mixed (5) & 2.1 & 5.7 & 8.7 & 16.5 & 5.1 & 4.2 & 12.6 & 21.9 \\
\hline Coniferous (3) & - & 3.9 & 7.8 & 11.7 & - & 1.3 & 12.8 & 14.1 \\
\hline
\end{tabular}


Table 2. Average standing crop of plants providing potential food for deer in deciduous mountain forest (Fagetum carpaticum). Calculations were based on Pucek (1982), Komorowska (1982)

\begin{tabular}{|c|c|c|c|c|c|c|}
\hline Season & $\begin{array}{c}\text { Basal tree area } \\
(\mathrm{sq} \mathrm{m} / \mathrm{ha})\end{array}$ & $\begin{array}{c}\text { Deciduous } \\
\text { browse }\end{array}$ & $\begin{array}{c}\text { Coniferous } \\
\text { browse }\end{array}$ & Herbs & $\begin{array}{c}\text { Grasses \& } \\
\text { sedges }\end{array}$ & Total \\
\hline \multirow{3}{*}{ Summer } & 30.2 & 20.2 & - & 33.3 & 58.3 & 111.8 \\
\hline & 22.5 & 27.2 & 22.1 & 38.3 & 5.3 & 92.9 \\
\hline & 16.9 & 52.5 & 4.1 & 112.0 & 20.8 & 189.4 \\
\hline \multirow{3}{*}{ Winter } & 30.2 & 10.4 & 0.6 & 2.8 & 0.1 & 13.9 \\
\hline & 22.5 & 13.7 & 22.1 & 10.1 & 1.1 & 47.0 \\
\hline & 16.9 & 27.1 & 4.1 & 16.1 & 2.8 & 50.1 \\
\hline
\end{tabular}

Table 3. Summer resources $\left(\mathrm{g} \mathrm{dw} / \mathrm{m}^{2}\right)$ of browse and ground flora (herbage + annual shoots of dwarf shrubs) in Bialowiesza Forest in fresh mixed coniferous stand exploited with clearcuts and in old growth forest, maintained as nature reserve sinve 1921 (Bobek, Kossak, Merta and Perzanowski, unpubl. data). The number of plant species constituting potential food supply for large herbivores is given in parentheses

\begin{tabular}{lrlrrrr}
\hline Commercial forest & \multicolumn{3}{c}{ Ground flora } & \multicolumn{2}{c}{ Browse } & \multicolumn{2}{c}{ Total } \\
\hline Young plantation & 128.7 & $(17)$ & 302.1 & $(10)$ & 430.8 & $(27)$ \\
Thicket & 16.5 & $(14)$ & 85.6 & $(10)$ & 102.1 & $(24)$ \\
$\begin{array}{l}\text { Mature forest } \\
\text { (timber stand) }\end{array}$ & 32.5 & $(23)$ & 38.6 & $(9)$ & 71.1 & $(32)$ \\
$\begin{array}{l}\text { Nature reserve } \\
\text { (old growth) }\end{array}$ & 18.2 & $(12)$ & 21.3 & $(5)$ & 39.6 & $(17)$ \\
\hline
\end{tabular}

habitats of animals and plants which, under regular logging procedure, are often destroyed.

A very important issue is finding a means to reduce damage caused by deer to plantations and thickets. Fencing is an expensive solution and it eliminates access to a considerable food resource that is not totally necessary for timber production. The optimal solution seems to be an increase of potential food supply in medium and mature age classes of forest, that are not sensitive to browsing and debarking. That may be achieved by: (1) maintaining low tree basal area in the forest, (2) including non-commercial tree species (e.g., poplar) in young plantations, and (3) maintaining or creating ecotones attractive to deer. Generally, the reduction of deer numbers does not result in a solution to the problem of forest damage. More likely solutions include the restoration of biodiversity and an increase in potential food resources for deer, possibly far from young plantations and thickets. Both could result from a better-planned rotation schedule for logging, that would create parts of forest very attractive to deer.

An improvement of wildlife habitats is a long-term, expensive procedure. It is already necessary to start an exchange of ideas between foresters and ecologists which, together with substantial legal changes, should finally allow the forests in Central Europe to become not only the source of timber, but to serve multiple functions including provision of wildlife and needs of modern societies.

\section{Acknowledgements}

Support for this study was partially provided by the grant GEF 05/21685 POL (Forest Biodiversity Protection Project) and FG-PO-386 grant under PL-480 USDA program.

\section{References}

Aulak, W. 1970. Studies on herb layer production in the Circao-Alnetum Oberd. 1953. Association. Ekol. Pol. A 18/19: 411-427.
Table 4. Summer resources $\left(\mathrm{g} \mathrm{dw} / \mathrm{m}^{2}\right)$ of browse and ground flora (herbage) in Bialowiesza Forest in fresh deciduous stands exploited by selective timber harvest system and in old growth stands maintained as nature reserve since 1921 (Bobek, Kossak, Merta and Perzanowski, unpubl. data). The number of plant species constituting potential food supply for large herbivores is given in parentheses

\begin{tabular}{lrrrrrr}
\hline Habitat & \multicolumn{2}{c}{ Herbage } & \multicolumn{2}{c}{ Browse } & \multicolumn{2}{c}{ Total } \\
\hline Commercial stand & 10.3 & $(23)$ & 3.2 & $(14)$ & 13.5 & $(37)$ \\
Old growth (reserve) & 8.7 & $(13)$ & 0.2 & $(7)$ & 8.9 & $(20)$ \\
\hline
\end{tabular}

Banasik, J. 1973. Ground flora production in a stand of TilioCarpinetum. Bull. Pol. Acad. Sci. Cl.II. 21: 593-599.

Bandola-Ciolczyk, E. 1974. Production of tree and energy flow through the litter in Tilio-Carpinetum association. Studia Naturae A 9: 29-91.

Barabasz, B. 1990. Zasobnosc pokarmowa siedliska boru swiezego dla jeleniowatych na przykladzie puszczy Rzepinskiej i Niepolomickiej. M.S. thesis, Jagiellonian University, Kraków.

Bobek, B., S. Borowski and R. Dzieciolowski. 1975. Browse supply ecosystems. Pol. Eco. Studd. 12: 17-32.

Bobek, B., M. Kosobucka, H. Krzakiewicz, K. Perzanowski and R. Wolf. 1990. Food, cover and human disturbance as factors influencing antlers weight in red deer. pp. 27-34. In S. Myrberget (ed). Trans. 19th Congress IUGB, Trondheim, Norway, 1989.

Bobek, B. and D. Merta. 1993. The effect of ecotones on the weight of red deer antlers in southeastern Poland. Trans. Int. Wildl. Manage. Congress. Costa Rica, 1993. (in press).

Bobek, B., K. Perzanowski and M. Bielak. 1990b. The analysis of forest habitats for successful roe and red deer management in Central Europe. pp. 82-86. In Wildlife conservation - present trends and perspectives for the 21 st century. Proc. Int. Symp. on Wildl. Conserv. Tsukuba and Yokohama, 1990.

Bobek, B., K. Perzanowski, J. Siwanowicz and J. Zielinski. 1979. Deer pressure on forage in a deciduous forest. Oikos 32: 373-380.

Bochnia, M. 1990. Zasobnosc bazy pokarmowej jeleniowatych w siedlisku boru mieszanego swiezego. M.S. thesis, Jagiellonian University, Kraków.

Dzieciolowski, R. 1969. The quality, quantity and seasonal variation of food resources available to red deer in various environmental conditions of forest management. Warsaw.

Dzieciolowski, R. 1970. Net primary production of herbaceous plants in four forest associations. Folia For. Pol. A. 16: 91-108. Golecki, Z. 1990. Zasobnosc bazy pokarmowej jeleniowatych w siedliskach boru mieszanego swiezego oraz lasu mieszanego swiezego w Puszczy Knyszynskiej i Rominckiej. M.S. thesis, Jagiellonian University, Kraków.

Harris, L.D. 1984. The fragmented forests. Univ. Chicago press, ChicagoLondon.

Komorowska, M. 1982. Wplyw gospodarki lesnej na zasobnosc runa lesnego dla jeleniowatych w Nadlesnictwie Piwniczna. M.S. thesis, Jagiellonian University, Kraków.

Moszynska, B. 1970. Estimation of the green top production of the 
herb layer in a bog pinewood Vaccinio uliginosi Pinetum. Ekol. Pol. A. 18: 779-803.

Myczkowski, S. 1967. Sklad florystyczny, struktura i produktywnosc roslinnosci drzewiastej platu Fagetum Carpaticum. Studia Naturae A 1: 61-93.

Mydlarz, J. 1976. Zasobnosc runa i jego wykorzystanie przez jeleniowate w borach Puszczy Niepolomickiej. M.S. thesis, Jagiellonian University, Kraków.

Myrberget, S. 1991. Game management in Europe outside of the Soviet Union. Trans. 18th Congress IUGB, Krakow 1987: 41-54.

Nabielec, J. 1988. Letnia zasobnosc pokarmowa boru mieszanego wilgotnego dla jeleniowatych w Puszczy Sandomierskiej. M.S. thesis, Jagiellonian University, Kraków.

Pucek, T. 1982. Wplyw gospodarki lesnej na zapas zeru pedowego w Nadlesnictwie Piwniczna. M.S. thesis, Jagiellonian University, Kraków.
Storch, I. 1993a. Habitat use and spacing capercaillie in relation to forest fragmentation patterns. Ph.D. dissertation, University of Munich.

Storch, I. 1993b. Pattern and strategies of winter habitat selection in alpine capercaillie. Ecography 16 (in press).

Vassant, J., J.M. Jullien, and S. Brandt. 1992. Reducing wild boar damage to wheat and oats in summer study of the effectiveness of maize distribution in the forest. Trans. 18th Congress IUGB, Kraków 1987. pp. 79-88.

Wojcik, Z. 1970. Primary production of the herb layer and plant fall in a dry pine forest (Cladonio-Pinetum) Kobendza 1930, in the Kampinos National Park. Ekol. Pol. a. 18: 393-409. 